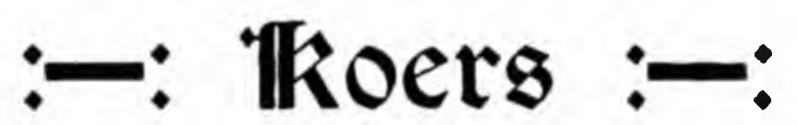

TWEEMAANDELIKSE TYDSKRIF

\begin{tabular}{lll}
\hline JAARGANG XXIV & OKTOBER 1956 & No. 2 \\
\hline
\end{tabular}

\title{
'N ERESALUUT AAN 'N AKADEMIKUS, PATRIOT EN LEIER
}

Hoewel Potchefstroom geen uitsaaistasie huisves nie, word daar dikwels in die gewone omgang van die stem van Potchefstroom gepraat. Ten beste word daarmee bedoel die besondere sterk leiding, veral prinsipieel, wat vanuit hierdie plek oor velerlei aangeleenthede die Afrikanervolk aangebied word. Maar die uitdrukking die stem van Potchefstroom is kollektief, en as sodanig is dit nodig dat dit soms gespesifiseer moet word.

Hoogswaarskynlik word geen geheim verklap met die mededeling dat prof. Dirk van Rooy 'n belangrike komponent van hierdie stem van Potchefstroom is nie. Soos die golfrimpels op 'n watervlak in steeds groter wordende kringe na die oewer beweeg, word die invloed van hierdie sterk en gebalanseerde man al ver buite sy tuiskring gewaar.

Natuurlik vind dit nie bloot toevallig plaas nie. Prof. van Rooy is toegerus met pragtige persoonlikheidsgawes soos meegaande artikels van twee persone wat hom besonderlik goed ken afdoende bewys. Teen die agtergrond van ' $n$ beminde en begaafde ouerpaar, van wie die moeder in haar lewe en die vader vandag nog 'n sieraad van die Afrikanervolk is, het sy talente 'n steeds hoër en magtiger vlug geneem, sodat hy vandag op sestigjarige leeftyd homself in die leier-corps op menige terrein bevind. En tog, daar in die voorste ry waar die kameraadskap soms gevaarlik yl kan 
word weens die sg. leiereensaamheid, dien sy natuurlike nederigheid en minsame beskeidenheid as behoudende faktore teen afdwaling na die woestyn van hooghartigheid en egoïsme. Sy leierskap berus tewens op die beginsel van strenge toepassing van regverdigheid en billikheid teenoor die beskouinge en belange van andere, sodat enersdenkendes hul hierdeur laat lei en andersdenkendes hom hierom respekteer. En les bes, gelukkig beoefen prof. Van Rooy nog die leierskap volgens opvatting in die Boerekommando's: die leier moet voor maar tog saam met sy mense ry.

Hierdie uitgawe van Koers is die veertiende wat 'n spesiale opdrag het, maar slegs die sesde waarmee 'n persoon in sy lewe vereer is. Die ander persone was Totius, proff. F. Postma, J. C. van Rooy, J. Chris. Coetzee, A. J. H. van der Walt en nou prof. D. J. van Rooy.

Toe die eerste nommer van Koers in Augustus 1933 verskyn het, was prof. D. J. van Rooy nie alleenlik een van die oorspronklike stigters nie, maar ook die sekretaris-penningmeester van die Direksie en een van die vier eerste redaksie-lede, van wie die ander drie proff. J. C. Coetzee, J. C. van Rooy en A. J. H. van der Walt was. Vir nie minder as tien jaar lank nie het prof. Van Rooy in hierdie hoedanigheid gedien, totdat hy in Desember 1943 uit die Redaksie en Direksie getree het. Baie treffend het die destydse hoofredakteur, prof. J. Chris Coetzee, soos volg van prof. Van Rooy se aandeel aan Koers getuig: „By die keuring was sy oordeel deurgaans deurslaggewend. Hy was besonder kieskeurig wat die gees en rigting en die wetenskaplike gehalte van die artikels betref..... Hy was 'n gereelde bydraer van fyn opgestelde, helder geformuleerde en goed deurdagte artikels" (Koers, Desember, 1943).

As ons let op die artikel-bydrae van prof. Van Rooy, spreek nie alleenlik die liefde vir die prinsipiële beskouing van sy vak daaruit nie, maar gewaar die leser 'n warmte om die hart deur so 'n aangrypende tinteling van patriotisme. Met albei voete stewig op vaderlandsgrond stel prof. Van Rooy onverbiddelik die Christelike voorgeslag se eis om handhawing van 'n duurgekoopte republikeinse erfenis en gaan soek hy veral die behoudenis daarvan in die Christelike onderwys. So skryf hy in Augustus 1933 (Jaargang I, no. I) oor C.N.O.: ,Daar gaan weer stemme op vir C.N.O. Goddank, want dis een van die tekens dat ons volk nog wil leef by die beginsels waaraan hy sy ontstaan en voortbestaan te danke het, en wat hom beskerm teen algehele ontaarding en verwording...... Wat is die Calvinistiese ideaal op onderwysgebied? Ons kan dit met een woord sê: gesonde, genoegsame ouerverteenwoordiging en ouerverantwoordelikheid". Laas- 
genoemde stelling tref my as een van die bondigste en korrekste weergawes van wat C.N.O. eintlik nastreef. Dit is 'n aksioom!

Dit is 'n voorreg vir die Redaksie van Koers om in die vier-en-twintigste jaargang hierdie uitgawe aan prof. Dirk van Rooy as een van die stigters en eerste redaksielede op te dra met die geleentheid van sy sestigste verjaarsdag. Dit is 'n eer om aan hom en mev. Van Rooy (wie se stille invloed vir die buitestander 'n onderwerp van interessante gissing maar vir die huiskring 'n voorwerp van hoogste waardering is) die opregbedoelde gelukwense met die behaalde lewensmylpaal oor te bring. Dit is 'n behoefte om met 'n gulle handdruk dankie te sê vir daadwerklike belangstelling, belangelose arbeid en veral warm, onweerstaanbare Boereliefde.

Namens die Redaksie,

\section{W. N. COETZEE,}

Hoofredakteur. 